\title{
Gandhi and the Development Discourse
}

Siby K. George is Professor of Philosophy at the Department of Humanities and Social Sciences, Indian Institute of Technology, Bombay. He is author of Heidegger and Development in the Global South (Springer, 2015), co-editor of Cultural Ontology of the Self in Pain (Springer, 2016) and Teaching in Unequal Societies (Bloomsbury, 2020), and of a number of journal papers and book chapters.

The figure of Gandhi as the man who distrusted, deconstructed and stood up to the colonizer's moral discourse has had abiding significance for the colonized part of the world. The central tenet of the Gandhian counternarrative is the rejection of developmental modernity and the portrayal of an alternative development model. The human and ecological crises of the twentieth century arose from the problems of modernity for Gandhi. As these problems further amplify, the Gandhian diagnosis becomes increasingly significant. However, a careful reading of the Gandhian critique of developmental modernity shows that he did not reject the moral, political and ontological underpinnings of modernity tout court. The answer to the problems of developmental modernity does not lie in a simple, unproblematic reversal as seen in the debates that Gandhi had with his critics on issues concerning development. The meaning of counterdevelopmentalism or postdevelopment must, therefore, be the reframing of the 'modern' quest for human freedom, fulfillment and equality without sidestepping the culture of wanton consumption.

Keywords: Development ethics, Post development, Modernity, Crisis, Alternatives.

\section{Introduction}

The subject matter of this paper is Gandhi's critique of developmental modernity, the contemporary significance of his critique, and the attendant questions of the sense of his critique and of the normative debate that it provoked. I discuss these questions in five sections. First, I emphasize the figure of Gandhi as the man who stood up to the colonizer's moral discourse. Second, I attempt to establish links between Gandhi's 


\section{2 / Siby K. George}

Salesian Journal of Humanities and Social Sciences, Vol. X, No. 2 (Dec 2019)

ISSN: 0976-1861 | 10.51818/SJHSS.10.2019.1-21 | Page: 1-21,

Section: Article

critique of developmental modernity and the concerns of contemporary postdevelopment theory, and of the subfield called 'development ethics'. I then move to develop Gandhi's ethical concerns with respect to developmental modernity in terms of his distinctive problematization of (third) the modern ecological crisis, and (fourth) the modern human crisis. Fifth, I discuss in conversation with Gandhi's critics the conception of an alternative modernity or postmodernity that can be discovered in his works.

\section{Gandhi and the Colonial Moral Discourse}

The figure of Gandhi is striking as the colonizer's antagonist, as the man who defied and stood up to the colonial moral discourse. Everyday social, political and personal human action is undergirded by moral discourses that mediate its sense of the good. ${ }^{1}$ But to be 'modern' means primarily to be exposed to moral discourses that initially shock our received moral sense. At the dawn of modernity in India, there was this incredible sense of shock, which later yielded to tame acceptance of the colonial moral discourse. Gandhi, however, tore into the colonial moral narrative,famously represented in Rudyard Kipling's verse," [t]ake up the White Man's burden - / Send forth the best ye breed - .../ To serve your captives' need;.../ Your new-caught, sullen peoples,/ Half-devil and half-child."2After analyzing the meaning of the word 'civilization', Gandhi hyperbolically declares in the Hind Swaraj (1909) that India "has nothing to learn from anybody else." ${ }^{3}$ Anticipating current fears, he argues that modern civilization is such that "one has only to be patient and it

\footnotetext{
${ }^{1}$ The connections between "senses of the self and moral visions, between identity and the good" is developed by Charles Taylor,Sources of the Self: The Making of Modern Identity (Cambridge, MA: Harvard University Press, 1989), x. He emphasizes the inescapability of the sense of the good, and how this sense, like all others, is caught up in the hermeneutical frame of the historical age.

${ }^{2}$ Rudyard Kipling, “The White Man's Burden” (1899). In Rudyard Kipling, The Collected Poems of Rudyard Kipling, (Hertfordshire: Wordsworth, 2001), 334.

${ }^{3}$ M. K. Gandhi, The Collected Works of Mahatma Gandhi, Vol.10, (New Delhi: The Publications Division of the Government of India, 1958-1994), 37. Subsequently these volumes are cited in the footnotes as CWMG, followed by the referred volume and page number(s).
} 
will be self-destroyed." ${ }^{4}$ Gandhi was called the Mahatma and Father of the Nation partly because there was a conscious effort from his part to arguably embody in his life, habits, clothing, body, personality and his enormously influential politics, the most distilled, idealized and thereby also somewhat utopian version of native culture.

Speaking of what comes to mind today with respect to the link between the figure of Gandhi and the development discourse, distanced as we are from his era by over seven decades, I think, he brings to the development discourse what philosopher Paul Ricoeur called the hermeneutics of suspicion'. Gandhi tore into the exploitative, condescending and unethical pedagogical mission of the colonizer, and cast a profound suspicion on the colonial discourse by "a tearing off of masks, an interpretation that reduces disguises." ${ }^{5}$ What he found fundamentally objectionable in modern civilization was the racist and unsustainable idea of linear, uniform, global progress. ${ }^{6}$ It is reported that for Gandhi the core of modern civilization can be expressed in two ways: "One was that it represented ceaseless activity, and the second was that it aimed at the annihilation of space and time. ... He found that the simple life was better than the complex, in that they [people] found time to devote attention to higher pursuits."7

I shall now proceed to relate Gandhi's critique to contemporary development critique, and show how the essential message of his critique has relevance for us today, although there is certainly an 'other' side to Gandhi's critique.

\section{Gandhi, Post development, Development ethics}

The Development Dictionary, an influential collection of critical essays by postdevelopment scholars, begins with a startling declaration, " $\mathrm{t}]$ he last

${ }^{4}$ Ibid, 21.

${ }^{5}$ Paul Ricoeur, Freud and Philosophy: An Essay on Interpretation, trans. Denis Savage, (New Haven, CT: Yale University Press, 1970), 30.

${ }^{6}$ See: Ashis Nancy, "From outside the Imperium: Gandhi's Cultural Critique of the 'West'”, Alternatives: Global, Local, Political 7, 2 (1981): 171-194.

${ }^{7}$ M K Gandhi, CWMG, 10: 279. 


\section{4 / Siby K. George}

Salesian Journal of Humanities and Social Sciences, Vol. X, No. 2 (Dec 2019)

ISSN: 0976-1861 | 10.51818/SJHSS.10.2019.1-21 | Page: 1-21,

Section: Article

40 years can be called the age of development. This epoch is coming to an end. The time is ripe to write its obituary." ${ }^{8}$ Postdevelopment is the deconstruction of the postwar western construction of the discourse of development pertaining to the global south and the reconstruction of development as decentralized, localized practices leading to more humanly fulfilling lives by and for the subjects of development themselves. There is certainly an element of radicalism in this school of thought, but my interest is in pointing out the Gandhian element in that radicalism, which a critical reviewer of four postdevelopment works did not miss, "[i]ndeed, there is not much that is new about post-development thought. For all its protestations of radical difference, there is little in post-development that moves beyond Gandhi or Schumacher, Illich or Fanon." ${ }^{\prime 9} \mathrm{My}$ point really is not to deny postdevelopment its originality, but to show how at least two of its concerns - the human and the environmental crisis - prefigure in Gandhi's rejection of the colonizer's civilizing mission.

Just as postdevelopment critics began to radically question and reject the postwar discourse of development, a second mode of questioning the conception of development began to emerge in the 1970s called 'development ethics'. If postdevelopment theory is largely influenced by the poststructural traditions of European thought, development ethics is based more in Anglo-American normative theory. Rather than proposing a straightforward rejection of the discourse of development, development ethics advocates normative criticism and re-strategizing of development action. But the concerns of development ethics are no less Gandhian. Denis Goulet, who is often mentioned as the pioneer of the new subdiscipline of development ethics, ${ }^{10}$ writes:

Gandhi, who was neither economist nor ethicist, formulated a vision and practice of development for India centered on values of nonviolent co-operation among social agents, responsible trusteeship in the

\footnotetext{
${ }^{8}$ Wolfgang Sachs, "Introduction", In The Development Dictionary: A Guide to Knowledge as Power, Second Edition, ed. Wolfgang Sachs, (London: Zed Books, 2010), xv.

${ }^{9}$ Stuart Corbridge, "'Beneath the Pavement Only Soil': The Poverty of Post-development", Journal of Development Studies 34, 6 (1998):145.

${ }^{10}$ David A. Crocker, “Toward Development Ethics”, World Development 19, 5 (1991): 458.
} 
ownership and administration of wealth, production by the masses over mass production, village development, and the provision of basic needs over the multiplication of wants... By centering his analysis and policy prescriptions on the values affected, Gandhi was acting, in effect, as a development ethicist. ${ }^{11}$

In the next two sections, my aim is to relate the concerns of development ethics and postdevelopment theory to Gandhi's diagnosis of the two crises of modernity. I begin with the ecological crisis, which for Gandhi arises essentially from a human-centric, developmentalist and unsustainable conception of good life.

\section{Gandhi and the Ecological Crisis}

Modern science and technology came into being in seventeenth-century Europe, and were conceived by Francis Bacon, Descartes and others as useful tools for material human progress. Bacon's sexist metaphor of a 'masculine', virile, generative science helped imagine the ceaseless progress of human society, aided by modern science. ${ }^{12}$ The mechanistic Newtonian understanding of the universe progressively emerged from the Baconian reduction of knowledge to its use for relieving 'man's estate', the Galilean mathematization of nature, and the dualistic Cartesian imagination that engraved on modern consciousness a sense of control of the fertile mind over inert matter. The utilitarian moral justification of liberal capitalism and western colonialism was the outcome of the age of reason and science; they were the material expression of the confidence in human progress that the spirit of science and reason gave to westerners. When Gandhi rejects modern civilization as represented in the machine culture, what he rejects is this particular history of the scientific culture that emerged out of the Enlightenment, the age of reason and the industrial revolution. It drove humanity to the present ecological crisis in a short span of just about four centuries. The concern about the dialectical

\footnotetext{
${ }^{11}$ Denis Goulet, “Development Ethics: A New Discipline”, International Journal of Social Economics 24, 11 (1997): 1161-62.

12 William Eamon, Science and the Secrets of Nature: Books of Secrets in Medieval and Early Modern Culture, (Princeton, NJ: Princeton University Press, 1996), 316.
} 


\section{6 / Siby K. George}

Salesian Journal of Humanities and Social Sciences, Vol. X, No. 2 (Dec 2019)

ISSN: 0976-1861 | 10.51818/SJHSS.10.2019.1-21 | Page: 1-21,

Section: Article

antithesis of modern technological culture is a global concern today, and it is undoubtedly a Gandhian concern.

Much before the ecological crisis became the talking point, arguably with the publication of Rachel Carson's Silent Spring(1962), Gandhi sounded ecological alarm bells in such counsel as the following to a capitalist in 1928:

God forbid that India should ever take to industrialism after the manner of the West. The economic imperialism of a single tiny island kingdom (England) is today keeping the world in chains. If an entire nation of 300 million took to similar economic exploitation, it would strip the world bare like locusts. ${ }^{13}$

Postdevelopment scholars agree that Gandhi's statement has greater relevance today, for "there are no longer 300 million but 1,000 million setting out to imitate Britain... The bio-physical limits to the spread of industrial civilization have impressively confirmed Gandhi's intuition." ${ }^{14}$ According to the deep ecologist Arne Næss, Gandhi showed him "the internal relation between self-realization, non-violence and what sometimes has been called biospherical egalitarianism." ${ }^{15}$ Gandhi's unwillingness to take the English path to development is rather historic because economic development, as an idea that emerged in seventeenth century England, was received in non-western countries as a short-cut to national power after the manner of the west. Reactive nationalism paved the way for the Meiji Restoration in Japan, and Dr. Sun Yat-Sen's call to modernization in China. ${ }^{16}$ Gandhi resisted the temptation, although Nehru and the other architects of independent India placed their faith in modernization

${ }^{13}$ M.K. Gandhi, CWMG 38: 243.

14 Wolfgang Sachs, "Fair Wealth: Pathways into Post-development", In Rethinking Development in a Carbon-Constrained World: Development Cooperation and Climate Change, ed. Eija Palosuo, (Helsinki, Finland: The Ministry for Foreign Affairs of Finland, 2009), 205.

${ }^{15}$ Arne Næss, "Self-realisation: An Ecological Approach to Being in the World", In Thinking Like a Mountain: Towards a Council of All Beings, ed. John Seed, Joanna Macy, Pat Fleming and Arne Næss, (Philadelphia, PA: New Society Publishers, 1988), 26.

${ }^{16}$ Heinz Wolfgang Arndt, Economic Development: The History of an Idea, (Chicago, IL: The University of Chicago Press, 1987), 13. 
after the manner of the west. Even still, it is useful to remember that the Gandhian hermeneutics of suspicion was a significant challenge posed to the idea of industrial modernity. Whenever we think of alternatives to industrial capitalism, we think of Gandhi. And Ramachandra Guha writes that "the life and practice of Gandhi are the single most important influence on the Indian environmental movement."17

The Gandhian alternative appears prophetic when we look at it with the benefit of the hindsight. For Gandhi, a consumerist civilization is not ecologically sustainable; rather, he prescribes a rural civilization in close contact with nature, but without the standard structures of the feudal society. He prescribes production in terms of need and not in terms of the abstract internal logic of the economy. He did not imagine the economy as a sphere that operated under precise, abstract laws, but one that obeyed human requirements and moral regulation. The idea of the productive process as a law unto itself, an abstract field of play with its own rules of the game, Gandhi feared, had led to a consumerist culture. Paul Gilding, an Australian environmentalist, argues in The Great Disruption (2011) that since we have only a single planet to support life, as far as we know, and since this planet has reached its breaking point as far as ecological sustainability is concerned, we as humans will soon have to find alternatives to our present mode of life, enmeshed in economism, developmentalism and endless shopping. Gilding writes, "I have no doubt we will respond - with intensity matching the crisis as it emerges - when we end our denial of the obvious logic we can all see if we choose to look." 18

There is today a noticeable degree of consensus across the world regarding the Gandhian ecological vision. We do not have the resources to lead such an expensive, inequitable, and inherently unjust lifestyle. Global justice requires that local abundance is globally distributed because local indulgence has global ramifications. It is true that we are struggling

${ }^{17}$ Ramachandra Guha, "Mahatma Gandhi and the Environmental Movement in India", Capitalism Nature Socialism 6, 3 (1995): 48.

${ }^{18}$ Paul Gilding, The Great Disruption: Why the Climate Crisis Will Bring on the End of Shopping and the Birth of a New World, (London: Bloomsbury, 2011), 94. 


\section{8 / Siby K. George}

Salesian Journal of Humanities and Social Sciences, Vol. X, No. 2 (Dec 2019)

ISSN: 0976-1861 | 10.51818/SJHSS.10.2019.1-21 | Page: 1-21,

Section: Article

presently to find solutions acceptable across the board, but we know that we are in a crisis. It takes time for us to register and respond to the demands that the crisis makes on our present way of life. The USA pulled out of the Kyoto protocol not because the climate crisis was not perceived as urgent but because, in the words of the senior President Bush, "the American way of life is not up for negotiation,"19 and in the words of his son, "Kyoto would have wrecked our economy." ${ }^{20}$ When humanity will be absolutely gripped by the crisis, our big shopping and consumerist culture will either come to a halt, or a new regime of terrorizing powerless countries to ecologically subsidize the profligate lifestyles of the rich will have to emerge, a new and ecologically compelled colonialism. What is becoming increasingly clear is that our intellectual window to a broadly Gandhian vision is gradually and ever so unwillingly opening up. The truth of Gandhi's statement, reported by his secretary Pyarelal, is now becoming unmistakably obvious, "Earth provides enough to satisfy every man's need but not for everyman's greed." ${ }^{21}$

I will now dwell on the human crisis - an instrumentalist, materialistic, self-obsessed and utilitarian disposition - that Gandhi feared was powering modern developmentalism.

\section{Gandhi and the Human Crisis}

The crisis of modernity, thus, is not predominantly ecological but human. It is human relation to the environment that is in crisis in the modern era. The meaning of the human has changed with modernity's unflinching humanism (human-centrism), in accordance with which unviable, unjust new systems and practices have emerged. With respect to the human crisis regarding developmentalism, Gandhi today appears even more prophetic.

19 Alan Atkisson, The Sustainability Transformation: How to Accelerate Positive Change in Challenging Times, (London: Earthscan, 2011), 220.

${ }^{20}$ Marcus G. Raskin, and Robert Spero,The Four Freedoms Under Siege: The Clear and Present Danger from Our National Security State , (Westport, CT: Praeger Publishers, 2007), 38.

${ }^{21}$ Pyarelal, Mahatma Gandhi, Vol. X: The Last Phase, Part-II ,(Ahmedabad: Navajivan, 1958), 552. 
What Gandhi criticizes the most in the modern civilization is the machine. In the Hind Swaraj he writes, "[m]achinery is the chief symbol of modern civilization; it represents a great sin." ${ }^{22}$ In this, Gandhi was influenced by Tolstoy and Ruskin. But the machine that Gandhi speaks about is not simply iron and steel, but a mode of human understanding, intervention and operation. For Gandhi, instrumental rationality and utilitarian morality are inherent aspects of modern technological civilization: machines make the human hand idle; it represents the evil power to destroy; it brings with its efficiency, superfluity, alienation and disruption of human bond.

Gandhi's philosophy of technology kept changing. In 1909, he wrote in the Hind Swaraj, "[i]t is machinery that has impoverished India..." 23 Again, "[i]t is necessary to realize that machinery is bad." ${ }^{24}$ But by 1946-47 Gandhi had changed his mind, "[w]e should be careful in using machines as a doctor is in prescribing poisonous medicines. Machine-power can make a valuable contribution towards economic progress. But a few capitalists have employed machine-power regardless of the interests of the common man and that is why our condition has deteriorated today." 25 He is now warning only against misuse, capitalistic greed and layoffs. Gandhi's call to be cautious about replacing the human hand with machine is especially relevant in labor-abundant and capital-scarce economies like India. It was the human crisis associated with technological culture that bothered Gandhi.

For Gandhi, the various facets of the human crisis included inequality, oppression of the poor and powerless, loss of spiritual orientation, materialism and the blind regimentation of life in accordance with the modern logic of efficiency. A strictly modernist manner of interpreting such a reading of contemporary decadence would make Gandhi appear outmoded and unmodern. But the fact is, he admired and advocated the

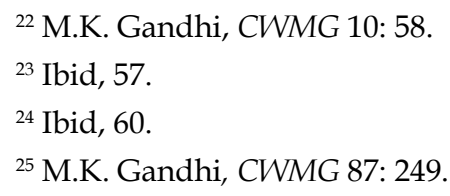




\section{0 / Siby K. George}

Salesian Journal of Humanities and Social Sciences, Vol. X, No. 2 (Dec 2019)

ISSN: 0976-1861 | 10.51818/SJHSS.10.2019.1-21 | Page: 1-21,

Section: Article

modern sense of freedom, equality and the human bond, and used to good effect several institutional and instrumental aspects of modernity such as the free press, the railways, the postal and legal systems, and he continuously invoked the modern sense of fairness, justice and the spirit of democracy.

A lot is made out of Gandhi's religion, his piety, saintliness and the spiritual metaphors that fill his writings and speeches. But what is forgotten is his "dislike of organized religion," "detestation of religious fundamentalism of all brands," his injunction to think of this world and not the other, his suspicion of ritualism. ${ }^{26}$ For a man who used fascinating metaphors and symbols to connect with the common person, his interreligious prayer meetings were like the 'salt' on Dandi beach - a moral and political symbol of harmony and freedom of spirit.

In fact, Gandhi diagnosed a paradox that concealed itself within the ethics of modernity. If freedom, equality and the human bond are valuable, then achieving the good life (development) and the new social order by means of technologically aided prosperity and bloody revolutions is meaningless. Technological society is neither environmentally sustainable nor humanly desirable; it tends to destroy the very freedom, equality and the human bond it promises to create. This resonates deeply with the Frankfurt School's and Heidegger's critique of technology, "[a] comfortable, smooth, reasonable, democratic unfreedom prevails in advanced industrial civilization, a token of technical progress." ${ }^{27}$ Hence, Gandhi resisted the European's missionary zeal to globalize the ethics of technological modernity. Gandhi was one of the first to systematically critique technological civilization. The more famous critique of technology of the French social critic Ivan Illich, the philosophical problematization of technology by the German philosopher Martin Heidegger and E. F. Schumacher's proposal of appropriate technology are foreshadowed in Gandhi's critique.

\footnotetext{
${ }^{26}$ Ajit K. Dasgupta, Gandhi's Economic Thought, (London: Routledge, 1996), 3-4.

${ }^{27}$ Herbert Marcuse, One-Dimensional Man: Studies in the Ideology of Advanced Industrial Society, (London: Routledge, 1991), 3.
} 
From a critique of the modern civilization, Gandhi developed the idea that economics and ethics cannot be separated. "True economics never militates against the highest ethical standard... True economics stands for social justice; it promotes the good of all equally, including the weakest and is indispensable for decent life." ${ }^{28}$ The effort of economists such as Amartya Sen to introduce ethical considerations into economic analysis, therefore, has a Gandhian lineage. In On Ethics and Economics, Amartya Sen complains, "[i]n the usual economic literature a person is seen as maximizing his utility function, which depends only on his own consumption, and which determines all his choices." ${ }^{29}$ Sen goes on to argue that ethical considerations will call for departures from standard behavioral assumptions of economic theory, and laments that at its origin economics was close to ethics and modern economics is 'impoverished' by the distance it maintained from ethics. Gandhi's economic ideas, on the other hand, arise from his deeply moral considerations. It is the concern for social justice that makes Gandhi support alternative technology like the charka, reject foreign goods and propose to the rich to act as trustees of their wealth for the benefit of society. Hence, the goal of development is sarvodaya or the welfare of all. "The fact is that a votary of ahimsa cannot subscribe to the utilitarian formula. He will strive for the greatest good of all and die in the attempt to realize the ideal." ${ }^{30}$ Gandhian development is the development of all in sharp contrast to the modern economic assumption of the self-interested economic agent, although he did not support the concept of class struggle. He did not believe in the neoliberal formula of trickle-down effect; rather, economic equality is part of his 1941 'constructive programme' towards Swaraj. Economic equality is, he wrote, "the master-key to non-violent independence. ...A nonviolent system of government is clearly an impossibility so long as the wide gulf between the rich and the hungry millions persists." ${ }^{11}$

\footnotetext{
${ }^{28}$ M.K. Gandhi, CWMG 66: 168.

${ }^{29}$ Amartya K. Sen, On Ethics and Economics (Malden, MA: Blackwell, 1987), 80.

${ }^{30}$ M.K. Gandhi, CWMG 32: 402.

${ }^{31}$ M.K. Gandhi, CWMG 75: 158.
} 


\section{2 / Siby K. George}

Salesian Journal of Humanities and Social Sciences, Vol. X, No. 2 (Dec 2019)

ISSN: 0976-1861 | 10.51818/SJHSS.10.2019.1-21 | Page: 1-21,

Section: Article

Moreover, for Gandhi it is not enough that goods are made available to all, but together with goods the agent of development should also experience a sense of independence and self-respect. The Gandhian development paradigm is incomplete without the Swaraj of the agent of development. ${ }^{32}$ In the words of the pioneer development ethicist Goulet, "[p]erhaps the only true universal value is the desire of all human persons, living in every place and under every cultural system, to be treated as beings of worth on their own terms and independently of their usefulness to others." ${ }^{33}$ In the words of Amartya Sen 'development is freedom', and in the Rawlsian scheme of just distribution, the social bases of self-respect is a primary good. In these ways, Gandhi is refreshingly present in today's subject-area of development ethics.

Gandhi believed in the connectedness of everything, and held that our actions have a ripple effect that affects the self, the other and all beings as the ethical Advaita of Swami Vivekananda reasoned. Gandhi was a spiritual leader primarily in this sense. For him self-realization was not merely an individual achievement but an achievement that had direct connection to reality around the person. "I believe in Advaita, I believe in the essential unity of man and for that matter of all that lives. Therefore I believe that if one man gains spiritually, the whole world gains with him and, if one man falls, the whole world falls to that extent. ${ }^{34}$ Hence, for Gandhi, the pursuit of development must be ethical; its measure, as in the Rawlsian difference principle, is the gain that it brings to the last person in the social and economic scheme. When in doubt about a scheme, Gandhi's injunction is to think of the face of the weakest and the poorest person and the scheme's use to her or him, whether it will lead to his or her Swaraj. ${ }^{35}$

\footnotetext{
${ }^{32}$ Thomas Weber, "Gandhi's Moral Economics: The Sins of Wealth without Work and Commerce without Morality", In The Cambridge Companion to Gandhi, eds. Judith M. Brown and Anthony Parel, (Cambridge: Cambridge University Press, 2011), 179.

${ }^{33}$ Denis Goulet, "In Defense of Cultural Rights: Technology, Tradition and Conflicting Models of Rationality," Human Rights Quarterly 3, 4 (1981): 4.

${ }^{34}$ M.K. Gandhi, CWMG 25: 390.

${ }^{35}$ Weber, "Gandhi's Moral Economics," 150.
} 
Gandhi is said to have idealized rural life, but it is to be emphasized that he was aware of criticism and did not endorse rural feudalism and despotism. He rather endorsed a network of interconnected and highly democratized village republics. Gandhi did not idealize the typical Indian village of his time. And so, the rural life Gandhi imagined was a category of its own. "We have got to be ideal villagers, not the villagers with their queer ideas, or absence of ideas, about sanitation and giving no thought to how they eat and what they eat ... We have to teach them how to economize in time, health and money. ${ }^{36}$ A frugal, dignified, satisfied, healthy life within considerably egalitarian rural republics was Gandhi's idea of development. While Gandhi valued community life, the cooperative scheme of society, and the interconnectedness of existence in general, he was not a communitarian like Charles Taylor. "Swaraj has to be experienced by each one for himself," ${ }^{37}$ remarks Gandhi, and the central focus of evaluation of wellbeing, as in the capabilities approach, should rest on the individual. Gandhi wrote the following to Nehru in 1945 while discussing the nature of the republic about to be free, "[t]he sum and substance of what I want to say is that the individual person should have control over the things that are necessary for the sustenance of life. If he cannot have such control the individual cannot survive. Ultimately, the world is made up only of individuals. If there were no drops there would be no ocean." ${ }^{38}$ Gandhi's ethical individualism is one aspect of his thought that strongly connects him with modern philosophy of the subject and development ethics. (I will discuss certain problems with this view of Gandhi in the next section.) In his debate with Nehru, Gandhi is aware that Nehruvian India may not follow his prescriptions. Reiterating his Hind Swaraj position of 1909, Gandhi tells Nehru that for the sake of true freedom for India and the world, people will have to live in villages and huts, not in cities and palaces, and pursue small-scale industries. Gandhi compares the mad rush for industrial progress with the dance of the proverbial moth around the flame that finally consumes

\footnotetext{
${ }^{36}$ M.K. Gandhi, CWMG 60: 251-52.

${ }^{37}$ M.K. Gandhi, CWMG 10: 39.

${ }^{38}$ M.K. Gandhi, CWMG 81: 320.
} 


\section{4 / Siby K. George}

Salesian Journal of Humanities and Social Sciences, Vol. X, No. 2 (Dec 2019)

ISSN: 0976-1861 | 10.51818/SJHSS.10.2019.1-21 | Page: 1-21,

Section: Article

it. He, therefore, considered it his bounden duty to set the alarm bells ringing. In his letter to Nehru, Gandhi goes on to describe the village of his imagination:

While I appreciate modern thought, I find that an ancient thing, considered in the light of this thought looks so sweet. You will not be able to understand me if you think that I am talking about the villages of today. My ideal village still exists only in my imagination. After all every human being lives in the world of his own imagination. In this village of my dreams the villager will not be dull - he will be all awareness. He will not live like an animal in filth and darkness. Men and women will live in freedom, prepared to face the whole world. There will be no plague, no cholera and no smallpox. Nobody will be allowed to be idle or to wallow in luxury. Everyone will have to do body labour. Granting all this, I can still envisage a number of things that will have to be organized on a large scale. Perhaps there will even be railways and also post and telegraph offices. I do not know what things there will be or will not be. Nor am I bothered about it. If I can make sure of the essential thing, other things will follow in due course. But if I give up the essential thing, I give up everything. ${ }^{39}$

For Gandhi, this portrait of social life is necessary because a life of truth, nonviolence and self-realization can be fulfilled in the best fashion only in the simplicity of village democracies. Violence and destruction, he held, would be the result of the accumulation of unnecessary wealth, giving rise to unsustainable structures and systems. This sort of localized, rural or at least hybrid forms of development that Gandhi imagined has gained currency in its postmodern, postdevelopment avatar. In Encountering Development, arguably the best known postdevelopment text, Arturo Escobar argues that:

Instead of searching for grand alternative models or strategies [of development], what is needed is the investigation of alternative representations and practices in concrete local settings, particularly as they exist in contexts of hybridization, collective action, and political mobilization. This proposal is developed in the context of the ecological 
phase of capital and the struggles over the world's biological diversity..$^{40}$

Notice that while rejecting the metanarrative of modernist development and the controlling, top-down developmental State, Gandhi did not reject the modern ideals of freedom, equality and solidarity, and he did not reject modern technology tout court. Hence, Escobar's 'contexts of hybridization' can be understood without undue interpretive violence through the eyes of the Gandhian development vision. Gandhi's solutions and yearnings were neither postmodern, or modern nor simply premodern; they were rather hybrid attempts of all these forms arising from his dissatisfaction with their contradictions.

My focus in the following closing section is on what could be concluded regarding alternative futures for humanity at large from the above discussion on Gandhi's relation to the contemporary critique of the discourse of development.

\section{Conclusion: Gandhi and Alternative Modernity}

The thin account of Gandhian alternative is simple. To achieve a free, healthy, self-actualizing, good life for everyone today and for generations to come, we need an austere regime of disciplined resource use. And in order to cultivate such discipline in a massive social scale, we need to reject the standard discourse of developmental modernity, its many (though not all) values and assumptions, and accept an alternative model of good life. The assumption that human beings function at best as self-centered atoms (individuals) who can cooperate only to get the best for their own selfgratification is a wrong way of procedure; this is neither the only way nor the best way of imagining social life. We can conceive society on a different set of assumptions of morally aware individuals, who willingly enter into a social scheme of cooperation. We cannot go on with the assumption that a highly technological civilization will do nothing to us, embodied, affective beings; we are affected by the phenomena of our world at every step. A technological mindset - a tendency to reduce things and people

\footnotetext{
${ }^{40}$ Arturo Escobar, Encountering Development: The Making and Unmaking of the Third World, (Princeton, NJ: Princeton University Press, 1995), 19.
} 


\section{6 / Siby K. George}

Salesian Journal of Humanities and Social Sciences, Vol. X, No. 2 (Dec 2019)

ISSN: 0976-1861 | 10.51818/SJHSS.10.2019.1-21 | Page: 1-21,

Section: Article

to their efficient use or resourcefulness - which is a consequence of the technological civilization, has led both to the human and the ecological crisis. Therefore, the technological discourse of development ought to be rejected in important ways, and a locally meaningful and democratized development practice should instead be embraced. I have argued that this Gandhian message has important connections with the concerns of postdevelopment as well as of development ethics.

My first response to the Gandhian alternative is that it is often jeered at or at best respectfully set aside as utopian and unfeasible because global humanity in contemporary times is swayed unmistakably by the postwar discourse of development and its promise of prosperity for all in equal measure. This aspiration is not simply a matter of western cultural imperialism alone, but a typically 'modern' aspiration and modern subjects all over the world are enthralled by it. The editor of The Development Dictionary, who projected postdevelopment as the obituary to the western development discourse in 1992, writes in his preface to the second edition in 2010 that postdevelopment scholars had not anticipated the fact that the global south is 'the staunchest defender of development', despite the fact that it was an invention and initially an imposition of the west. "Countries in general do not aspire to become more 'Indian', more 'Brazilian' or for that matter more 'Islamic'; instead, assertions to the contrary notwithstanding, they long to achieve industrial modernity." ${ }^{41}$ Gandhi's reconstruction of alternative modernity - a society that lives in free collaboration, friendship, trust, social equality, health and harmony with nature - is unfeasible to the extent that there is a deep, uncritical penetration of the postwar development discourse in societies all over the world.

My second response, however, is that in revisiting Gandhi, his shocking views on modern civilization's developmental project and his alternative paradigm, there is the need to exercise caution because in invoking Gandhi for one's projects in a piecemeal fashion - say, in saving

${ }^{41}$ Wolfgang Sachs, "Preface to the New Edition", In The Development Dictionary: A Guide to Knowledge as Power, Second Edition, ed. Wolfgang Sachs, (London: Zed Books, 2010), viii-ix. 
trees - it must be remembered that the Gandhian approach implies a deep and radical confrontation with modernity. Such is the vision of the Hind Swaraj, which he is said to have defended till the end. We need to discover for ourselves the meaning of his radical vision. Intellectually, Gandhi was an eclectic assimilationist, who always experimented with his 'truths', especially the truths he set forth in 1909 in the Hind Swaraj. In practicing this vision, Gandhi himself engaged with it continuously; his was a constant interpretive project. So while the Hind Swaraj rejects the railways, the lawyers, the doctors, the postmen/women and the media - all symbols of modern civilization - Gandhi used them himself and, as I have noted above, gradually tempered his views on technology. That is, the vision was coming alive in Gandhi's life too. His writings and his life together form a text for us to read, reflect over and interpret in the Derridean sense. If anything, a genuinely Gandhian approach is that of the searcher, who is willing to risk one's own interpretation of events, goals and life.

Gandhi's confrontational approach to modernity is variously criticized. His glorification of rural civilization was objectionable to Ambedkar. He famously castigated Gandhians, who eulogized the Indian village, in the Constituent Assembly on 4 November 1948, " $[w]$ hat is the village but a sink of localism, a den of ignorance, narrow-mindedness and communalism?" 42 Although Gandhi was painting an imagined ideal village as I have shown in the last section, if the Indian village was to form the organizing nucleus of Indian politics, this would then have real

42 B. R. Ambedkar, Dr. Babasaheb Ambedkar: Writings and Speeches, Vol. 13, ed. Vasant Moon, (Bombay: Education Department of the Government of Maharashtra, 1994), 62. In Nehru's reply to Gandhi's letter of 1945, which I have discussed in the last section, he also agrees with Ambedkar. "I do not understand why a village should necessarily embody truth and non-violence. A village, normally speaking, is backward intellectually and culturally and no progress can be made from a backward environment. Narrowminded people are much more likely to be untruthful and violent." Jawaharlal Nehru, "Nehru's Reply to Gandhi." In M. K. Gandhi, Hind Swaraj and other Writings, ed. Anthony P. Parel, (Cambridge: Cambridge University Press, 1997),152. Nehru also adds: "I do not think it is possible for India to be really independent unless she is a technically advanced country" (153). On the debate between Gandhi, Nehru and Ambedkar on this problem, see: Surinder S. Jodhka, "Nation and Village: Images of Rural India in Gandhi, Nehru and Ambedkar", Economic and Political Weekly 37, 32 (2002): 3343-3353. 


\section{8 / Siby K. George}

Salesian Journal of Humanities and Social Sciences, Vol. X, No. 2 (Dec 2019)

ISSN: 0976-1861 | 10.51818/SJHSS.10.2019.1-21 | Page: 1-21,

Section: Article

consequences. Moreover, Gandhi's reluctance in addressing the issue of radically transforming the caste structure of society hanged like the sword of Damocles on his alternative social vision. It must be kept in mind that marginalized Indians, Dalits and Adivasis, consider the modern period as the best in their history. ${ }^{43}$ As late as in 1936 Gandhi's article "The Ideal Bhangi", appears to condescendingly idealize the demeaning caste-based occupation of hereditary manual scavenging. ${ }^{44}$ Gandhi did not seem to have believed in the destruction of the caste system. In 1925, when he was told about Narayana Guru from Travancore as a great Sanskrit scholar from a Shudra caste, Gandhi dissuaded his readers in a published note from considering him a Brahmin. "He who performs the duty of a Brahmin will easily become one in the next incarnation. But a translation from one varna to another in the present incarnation must result in a great deal of fraud. The natural consequence must be the obliteration [of] varna. I have seen no reason to justify its destruction." ${ }^{45}$ Ambedkar's confrontations with Gandhi regarding the Poona Pact (1932) are wellknown. Considering Gandhi's views on caste, therefore, Ambedkar's bone of contention with the Gandhian objection to modern civilization and technology is noteworthy, it is born from an unwillingness to address unjust social organization so that "benefits will not be usurped by the few

${ }^{43}$ Partha Chatterjee recollects a Dalit activist's disdain for intellectual discourse about the collapse of political morality in contemporary India. "[T]he latter half of the twentieth century had been the brightest period inthe entire history of the Dalits, since they had got rid of the worst forms of untouchability, mobilized themselves politically as a community, and were now making strategic alliances with other oppressed groups in order to get a share of governmental power." Partha Chatterjee, The Politics of the Governed: Reflections on Popular Politics in Most of the World, (New York: Columbia University Press, 2004), 25. Similarly, Ramachandra Guha recollects the Kannada Dalit poet Devanur Mahadeva's comparison between Gandhi and Ambedkar. "Modernity, not tradition; development, not stagnation, were responsible for Ambedkar as sartorial inversion of Gandhi, for his successful yet all-too-infrequent storming of the upper-caste citadel." Guha, How much should a Person Consume?,243.

${ }^{44}$ M.K. Gandhi, CWMG 64: 86-88; For an analysis of Ambedkar's confrontation with Gandhi on caste-related politics, see: Arundhati Roy, "The Doctor and the Saint", In B.R. Ambedkar, Annihilation of Caste: The Annotated Critical Edition, (New Delhi: Navayana, 2014), 15-179.

${ }^{45}$ M.K. Gandhi, CWMG 26: 538. 
but will accrue to all." ${ }^{46}$

Similarly, the Marxist critique of Gandhi's approach to class-structure is also well-known. Regarding the notion of trusteeship, Phyllis Rolnick argues that for Gandhi, removal of class distinction was neither possible nor desirable, and so he, "laid the burden of giving to the poor upon the rich, and discouraged the poor from showing impatience or taking any action bordering on violence." ${ }^{47}$ Gandhi's reply to Zamindars in 1934, reassuring them that class war will not be permitted in India, shows a certain reluctance to transform land relations, which still remains an unjust and thorny issue in India:

You may be sure that I shall throw the whole weight of my influence in preventing class war... But supposing that there is an attempt unjustly to deprive you of your property, you will find me fighting on your side... Our socialism or communism should therefore be based on non-violence and on the harmonious co-operation of labour and capital and the landlord and the tenant. ${ }^{48}$

In his conversation with the Zamindars, Gandhi held that class conflict was opposed to the 'essential genius of India', and that the Ramarajya of his dreams was a rule that would ensure 'rights alike of prince and pauper'. Such views cast doubt on the Gandhian approach towards social justice.

Tagore made a case against unreason in his debate with Gandhi on the call to spin and weave the charka and burn foreign clothes. The blind call to spin the charka is, for Tagore, no different from offering tomatoes to Lord Jagannath. ${ }^{49}$ While denouncing with Gandhi the mechanical, regimental logic of technological systems, organizations and modern

\footnotetext{
${ }^{46}$ B. R. Ambedkar, Dr. Babasaheb Ambedkar: Writings and Speeches, Vol. 9, ed. Vasant Moon (Bombay: Education Department of the Government of Maharashtra, 1991), 283.

${ }^{47}$ Phyllis J. Rolnick, "Charity, Trusteeship, and Social Change in India: A Study of a Political Ideology." World Politics 14, 3 (1962): 448.

${ }^{48}$ M.K. Gandhi, CWMG 58: 248.

${ }^{49}$ See: Rabindranath Tagore, "Creative Unity", In The English Writings of Rabindranath Tagore, Vol. 3, ed. Sisir Kumar Das, (New Delhi: Sahitya Akademi, 1996), 538-548.
} 


\section{0 / Siby K. George}

Salesian Journal of Humanities and Social Sciences, Vol. X, No. 2 (Dec 2019)

ISSN: 0976-1861 | 10.51818/SJHSS.10.2019.1-21 | Page: 1-21,

Section: Article

machinery, Tagore also held that, "the machine has its place in this world. And not only this material universe, but human beings also, may be used as machines and made to yield powerful results. This aspect of truth cannot be ignored; it has to be known and mastered. Europe has done so and has reaped a rich harvest." ${ }^{50}$ Thus, all things considered, in critically reassessing postwar developmentalism, the Gandhian diagnosis of the ecological and human crisis is perfectly accurate, but his reluctance to transform traditional systems of social relations is problematic. The ecological Gandhi is paradigmatic, but the sociopolitical Gandhi is flawed because his solutions are individual-centered rather than structurally transformative. Gandhi's anxiety about violence makes him appear a conservative gradualist.

Guha discusses the above problem in connection with Indian environmentalism. He argues that Gandhi's life is an example of making "remarkably few demands on the earth." ${ }^{11}$ At the same time, Guha maintains, it is incorrect to romanticize Gandhi's idealization of rural life as the Chipko and the Narmada movements have done. That is, it is unfair to think that people who live near the ecosystem, rural Indians and Adivasis, want to (and should) remain where they are because they abhor the city and its opportunities. For Guha, the more just and practical manner of addressing politically the asymmetries of distribution of the world's resources, would be to empower, "ecological refugees and ecosystem people, strengthening their ability to govern their lives and gain from the transformation of nature to artifact." 52 According to Guha, the social ecological question of how equitably are natural resources/produces distributed, which is the question of development, and a politics centered on that question would force people who lead a resource-intensive lifestyle - the global omnivores - to bear the cost of their profligate lifestyle. If overconsumption is a problem, so is underconsumption. Violence is unethical not only when it is employed to rectify

\footnotetext{
${ }^{50} \mathrm{Ibid}, 512$.

${ }^{51}$ Guha, "Mahatma Gandhi and the Environmental Movement in India," 60.

52 Ramachandra Guha, How much should a Person Consume? : Thinking through the Environment, (Ranikhet: Permanent Black, 2006), 244.
} 
injustice. Unjust social systems themselves are violent. Thus, the politics of frugality and equality must go together. In a similar vein, if we were to envisage sociopolitical solutions to any development-related concern such as redistribution of land and opportunities, our solutions must be necessarily structural rather than based on individual largesse, acts of good will and heroism. Solutions must also be 'modern' even as the dark sides of modernity are critically rejected.

The Gandhi who said no to the moral discourse of the imperialist colonial empire is today reconsidered by some as the Postmodern Gandhi because he challenged three established orders, "the ritual order of upper caste Hinduism," "the high modernism of the Nehruvian Congress," and "modern civilization." ${ }^{53}$ I have argued that the alternative modernity or postmodernity of frugality and equality that Gandhi proposed could be reconsidered by envisaging social changes structurally rather than in terms of individual forms of simple living. This would, however, demand reconsideration of Gandhian gradualism and fetishism of non-violent methods of appeasing errant social agents and groups.

${ }^{53}$ Lloyd I. Rudolph and Susanne Hoeber Rudolph, Postmodern Gandhi and Other Essays: Gandhi in the World and at Home, (Chicago, IL: The University of Chicago Press, 2006), 3. 